\title{
LOW CONCENTRATION OF HEAVY METAL SELENIUM EFFECT ON MILK SOMATIC CELL COUNT IN DAIRY COWS
}

\author{
Ivana Davidov ${ }^{1}$, Miodrag Radinović ${ }^{1}$, Zorana Kovačević ${ }^{1}$, Mira Pucarević ${ }^{2}$, \\ Nataša Stojić ${ }^{2}$, Dragica Stojanović ${ }^{1}$ \\ ${ }^{1}$ Department of Veterinary Medicine, Faculty of Agriculture, University of Novi Sad, \\ 21000 Novi Sad, Serbia \\ ${ }^{2}$ Faculty of Environmental Protection, Educons University, \\ 21208 Sremska Kamenica, Serbia \\ ivana.davidov@polj.edu.rs
}

\begin{abstract}
The aim of this study was to determine the influence of low concentration on heavy metal selenium on milk somatic cell count in dairy cows. Selenium acts as a cellular antioxidant in the cell cytoplasm by preventing cell damage. Milk quality is primarily measured through somatic cell count. The experiment included thirty high-yielding Holstein cows. After measuring blood serum selenium concentration of dairy cows, the average selenium concentration in the blood serum was $0.53 \pm 0.11 \mathrm{mmol} / \mathrm{l}$ and the average somatic cell count was $457 \pm 84(000 / \mathrm{ml})$. The low levels of selenium in blood serum caused increasing number of milk somatic cell count that gives negative correlation according to correlation test. Changes caused by low concentration of heavy metal selenium occur due to marked inflammation process in the cow udder. Results showed that heavy metal selenium has a significant impact on udder health.
\end{abstract}

Key words: heavy metal selenium; somatic cell count; dairy cows

\section{ВЛИЈАНИЕ НА НИСКОТО НИВО НА КОНЦЕНТРАЦИЈА НА ТЕШКИОТ МЕТАЛ СЕЛЕН ВРЗ БРОЈОТ НА СОМАТСКИТЕ КЛЕТКИ ВО МЛЕКОТО НА МОЛЗНИТЕ КРАВИ}

\begin{abstract}
Целта на оваа студија беше да го утврди влијанието на ниската концентрација на тешкиот метал селен врз бројот на соматските клетки во млекото на молзните крави. Селенот дејствува како антиоксиданс врз клетките на цитоплазмата при спречување оштетување на клетките. Квалитетот на млекото првенствено се мери преку бројот на соматските клетки. Експериментот вклучи 30 високопродуктивни крави од расата холштајн.Според мерењето концентрацијата на селен во крвниот серум на молзните крави беше $0.53 \pm 0.11 \mathrm{mmol} / \mathrm{l}$, а просечниот број на соматските клетки беше $457 \pm 84(000 / \mathrm{ml})$. Според тестот за корелација, негативната корелација на концентрацијата на селен во крвта и бројот на соматските клетки во млекото настана поради ниско ниво на селен во крвта што предизвика зголемен број на соматските клетки во млекото. Промените предизвикани од ниската концентрација на тешкиот метал селен се појавуваат при воспалителен процес на вимето на кравата. Резултатите покажаа дека тешкиот метал селен има значително влијание врз здравјето на вимето.
\end{abstract}

Клучни зборови: тежок метал селен; број на соматски клетки; молзни крави

\section{INTRODUCTION}

Selenium as trace element and heavy metal as well, has essential importance in maintaining udder health of dairy cows (Andrieu, 2008), acting as a cellular antioxidant in the cell cytoplasm by preventing cell damage due to peroxidase, and plays major role in the function of the immune response (Miller et al., 1993). Uncontrolled peroxidase is highly damaging to healthy cells and healthy tissue of the cow udder (Kommisrud et al., 2005). Selenium is essential in helping leukocytes to reduce the formation of peroxidase, to translate them into safe substance and to destroy phagocytized pathogens (Larsen, 1993; Finch and Turner, 1996; Smith et al., 1997; McKenzie et al., 1998). Selenium, also provide a solid udder first line against environmental microorganisms (Sordillo et al., 1997).

The dietary selenium requirement is important for dairy cows health, and has been associated with 
a reduction in somatic cell count (Weiss et al., 1990; Weiss, 2002). Selenium supplementation of dairy cows diets may also enhance the nutritional quality of dairy products (Juniper et al., 2006). Milk quality is primarily measured through somatic cell count. Somatic cells are mainly milk-secreting epithelial cells that have been shed from the lining of the gland and white blood cells (leukocytes) that have entered the mammary gland in response to injury or infection. The milk somatic cells include $75 \%$ leucocytes, i.e. neutrophils, macrophages, lymphocytes, erythrocytes, and 25\% epithelial cells (Sharma et al., 2011). Milk that is from uninfected quarters generally has a somatic cell count of $200,000 / \mathrm{ml}$ or less. A somatic cell count of $500,000 / \mathrm{ml}$ or more indicates an inflammation of the udder (Boboš et al., 1997).

The aim of this study was to determine the influence of low concentration on heavy metal selenium on milk somatic cell count in dairy cows.

\section{MATERIALS AND METHODS}

\section{Animals}

The study was performed on thirty Holstein cows approximate same body weight, ages 3 to 5 years and they giving approximately the same amount of milk. All thirty cows raised under farm conditions with dry straw for bedding and with ad libitum access to potable water.

\section{Blood analysis}

Blood samples were taken after morning milking from the caudal vein by applying the principles of asepsis and antisepsis. Tubes with appropriate needle were used for taking blood. The blood in tubes was left at room temperature for 24 hours to separate the serum. Blood sera were further analyzed by atomic absorption spectrometry (AAS).

\section{Milk analysis}

Milk samples taken at time of blood sampling. Milk from all four quarters was taken during morning milking and whole milk samples were taken with milk meter for somatic cell count. When quarter milk samples were taken the teat ends were disinfected. Somatic cell count (SCC) was determined using MILKOSCAN appliances.

\section{Statistical analysis}

The findings were evaluated using test of correlation between heavy metal selenium blood concentration and milk somatic cell count. The evaluation was performed using Microsoft Excel 2007 Software.

\section{RESULTS AND DISCUSSION}

After measuring blood serum selenium concentration of dairy cows, the average selenium concentration in the blood serum was $0.53 \pm 0.11$ $\mathrm{mmol} / \mathrm{l}$ and the average somatic cell count was 457 $\pm 84(000 / \mathrm{ml})$. Number of cows with low concentration on heavy metal selenium and number of somatic cell count (SCC) are shown in Table 1.

Table 1

Blood serum selenium concentration and somatic cell count in dairy cows

\begin{tabular}{lcc}
\hline \hline & No. of cows & SCC (000/ml) \\
\hline $\begin{array}{l}\text { Blood selenium conc. } \\
0.2-0.5 \mathrm{mmol} / \mathrm{l}\end{array}$ & 17 & $570-410$ \\
Blood selenium conc. & 13 & $400-310$ \\
$0.6-0.9 \mathrm{mmol} / \mathrm{l}$ & 30 & \\
Total & & \\
\hline
\end{tabular}

According to Table 2, it was noticed that there was a negative correlation within blood serum selenium concentration and milk somatic cell count because the low levels of selenium in blood serum caused increasing number of milk somatic cell count.

Table 2

Test correlation between selenium blood concentration and milk somatic cell count

\begin{tabular}{ccc}
\hline \hline $\begin{array}{c}\text { SCC } \\
(000 / \mathrm{ml})\end{array}$ & $\begin{array}{c}\text { Blood selenium } \\
\text { conc. }\end{array}$ & $n=30$ \\
\hline $320-380$ & $0-0.24$ & 5 \\
$390-450$ & $0.25-0.49$ & 12 \\
$460-530$ & $0.5-0.74$ & 8 \\
$540-580$ & $0.75-1$ & 5 \\
\hline & & $-0.89935^{*}$ \\
\hline
\end{tabular}

*Negative correlation 
The mean estimate of selenium blood serum concentration was $0.536 \mu \mathrm{mol} / 1$ and standard deviation was 0.224789. Average somatic cell was $450.000 / \mathrm{ml}$ of milk and $56.67 \%$ of the cows was over $450.000 / \mathrm{ml}$ with standard deviation 73.68853 .

The range of physiological values for blood selenium in dairy cows is 0.6 to $0.9 \mathrm{mmol} / \mathrm{l}$ (Eredljan et al., 2011; Juniper et al., 2006; Gunter et al., 2003). Pechová et al. (2008) reported that is no singificant correlation between blood selenium concentration and milk selenium concentration. However, Davidov et al. (2013) found a negative correlation within blood serum selenium concentration and milk somatic cell count because the increasing levels of selenium in blood serum cause a decline in the number of milk somatic cell count. This occurs because selenium deficiency provokes an inflammatory process due to reduced antioxidant activity in tissues when there is an accumulation of immune cells in response to prolonged inflammation.

The concentration of selenium negatively correlated with the degree of cellular infiltration in the parenchyma of the mammary gland. Selenium supplementation leads to reduction in subclinical mastitis and somatic cell count in dairy cows (Barbano et al., 2006; Rabiee et al., 2010; Wiess, 2002; Davidov et al., 2012). A reduction in somatic cell count and the low incidence of mastitis are present with blood serum selenium concentration with estimate value $0.601 \mu \mathrm{mol} / \mathrm{l}$. This results are matched with group of authors Weiss et al. (1990); Weiss (2002); Juniper et al. (2006); Phipps et al. (2008); Davidov et al. (2011), who claim that selenium have an important influence on reducing somatic cell count.

\section{CONCLUSION}

Heavy metal selenium as trace element plays important role of proper functioning of cow udder. Low selenium blood serum concentration is negatively correlated with somatic cell count. That low concentration increase milk somatic cell count which can be lead to inflammation in parenchyma of cow udder.

\section{REFERENCES}

[1] Andrieu, S.: Is the role for organic trace element supplements in transition cow health? Vet J, 176, 77-83 (2008).

[2] Barbano, D. M., Ma, Y., Santos, M. V.: Influence of raw milk quality on fluid milk shelf life. J Dairy Sci., 89, 1519 (2006).

[3] Boboš, S., Stojanović, L., Vidić, B., Bugarski, D.: Brojanje somatskih ćelija u mleku krava radi dijagonstikovanja i praćenja infekcije vimena i stada. Veterinarski glasnik, 51 (9-10), 481-589 (1997).

[4] Davidov, I., Radinović, M., Erdeljan, M., Belić, B., Cincović, M. R., Boboš, S.: Blood selenium concentration, somatic cell count and their correlation at first and sixth month of lactation in dairy cows. Contemporary Agriculture, 61 (1-2), 95-103 (2012).

[5] Davidov, I., Erdeljan, M., Radinović, M., Stančić, I., Kovačević, Z.: Blood selenium concentration affect mastitis and milk quality in dairy cows, JMBFS, 2 (special issue 1), 1147-1154, 2013.

[6] Davidov, I., Radinović, M., Boboš, S., Erdeljan, M.: Influence of selenium on mamary glands and milk somatic cells in dairy cows. Contemporary Agriculture, 60 (3-4), 342347 (2011).

[7] Erdeljan, M., Davidov, I., Boboš, S., Radinović, M., Stančić, I.: Nalaz nivoa selena u krvnom serumu kod karava u laktaciji. Letopis naučnih radova Poljoprivrednog fakulteta u Novom Sadu, 35 (1), 104-109 (2011).

[8] Finch, J. M., Turner, R. J.: Effects of selenium and vitamin $\mathrm{E}$ on the immune response of domestic animals. Res Vet Sci., 60, 97-106 (1996).

[9] Grace, N. D., Ankenbauer-Perkins, K. L., Alexander, A. M., Marchant, R. M.: Relationship between blood selenium concentration or glutathione peroxidase activity, and milk selenium concentrations in New Zealand dairy cows. NZ Vet J., 49 (1), 24-28 (2001).

[10] Gunter, S. A., Beck, P. A., Phillips, J. M.: Effects of supplementary selenium source on the performance and blood measurements in beef cows and their calves. J Anim Sci., 81, 856-864 (2003).

[11] Juniper, D. T., Phipps, R. H., Jones, A. K., Bertin, G.: Selenium supplementation of lactating dairy cows: the effect on selenium concentration in blood, milk, urine and feces. J Dairy Sci., 89, 3544-3551 (2006).

[12] Kommisrud, E., Osteras, O., Vatn, T.: Blood selenium associated with health and fertility in Norwegian dairy herds. Acta Vet Scand, 46, 229-240 (2005).

[13] Larsen, H. J. S.: Relation between selenium and immunity. Nor J Agric Sci., 11, 105-119 (1993).

[14] McKenzie, R. C., Rafferty, T. S., Beckett, G. J.: Selenium: an essential element for immune function. Immunol Today, 19, 324-345 (1998).

[15] Miller, J. K., Brzezinska-Slebodzinska, E., Madsen, F. C.: Oxidtive stress, antioxidants and animal function. J Dairy Sci., 76, 2812-2823 (1993).

[16] Pechová, A., Pavlata, L., Dvořák, R., Lajková, E.: Contents of $\mathrm{Zn}, \mathrm{Cu}, \mathrm{Mn}$, and Se in milk in releation to their concentrations in blood, milk yield and stages of lactation in dairy cattle. Acta Vet Brno, 77, 523-531 (2008).

[17] Phipps, R. H., Grandison, A. S., Jones, A. K., Juniper, D. T., Ramosmorales, E., Bertin, G.: Selenium supplementation of lactating dairy cows: effects on milk production and total selenium content and speciation in blood, milk and cheese. Animal, 2 (11), 1610-1618 (2008).

[18] Rabiee, A. R., Lean, I. J., Stevenson, M. A., Socha, M. T.: Effects of feeding organic trace minerals on milk production and reproductive performance in lactating dairy cows: a mta-analysis. J Dairy Sci., 93 (9) 4239-4251 (2010). 
[19] Sharma, N., Singh N. K., Bhadwal, M. S.: Relationship of somatic cell count and mastitis: An overview. Asian-Aust. J. Anim. Sci., 24 (3), 429-438 (2011).

[20] Smith, K. L., Hogan, J. S., Weiss, W. P.: Dietary vitamin $\mathrm{E}$ and selenium affect mastitis and milk quality. $J$ Anim Sci. 75, 1659-1665 (1997).

[21] Sordillo, L. M., Shafer-Weaver, K., De Rosa, D.: Immunobiology of the mammary gland. J Dairy Sci., 80: 185165 (1997).
[22] Weiss, W. P., Todhunter, D. A., Hogan, J. S., Smith, K. L.: Effect of duration of supplamentation of selenium and vitamin E on periparturient dairy cows. J. Dairy Sci., 73, 3187-3194 (1990).

[23] Weiss, W. P.: Relatioship of mineral and vitamin supplementation with mastitis and milk quality. In: Proc. Annual Meeting, National Mastitis Concil, Orlando, Florida, USA, 37-44, 2002. 